\title{
Neurosteroids as Selective Inhibitors of Glycine Receptor Activity: Structure-Activity Relationship Study on Endogenous Androstanes and Androstenes
}

\author{
Julia V. Bukanova ${ }^{1}$, Elena I. Solntseva ${ }^{1 *}$ and Eva Kudova ${ }^{2 *}$ \\ ${ }^{1}$ Research Center of Neurology, Moscow, Russia, ${ }^{2}$ Institute of Organic Chemistry and Biochemistry, Czech Academy \\ of Sciences, Prague, Czechia
}

The ability of androstane and androstene neurosteroids with modifications at C-17, C-5, and C-3 (compounds 1-9) to influence the functional activity of inhibitory glycine and $\gamma$-aminobutyric acid (GABA) receptors was estimated. The glycine- and GABAinduced chloride current ( $I_{\text {Gly }}$ and $I_{\text {GABA }}$ ) were measured in isolated pyramidal neurons of the rat hippocampus and isolated rat cerebellar Purkinje cells, correspondingly, using the patch-clamp technique. Our results demonstrate that all the nine neurosteroids display similar biological activity, namely, they strongly inhibited /Gly and weakly

OPEN ACCESS

Edited by:

Steven James Mennerick, Washington University in St. Louis,

United States

Reviewed by:

Joseph Henry Steinbach, Washington University in St. Louis,

United States

Enrico Sanna,

University of Cagliari, Italy

${ }^{*}$ Correspondence:

Elena I. Solntseva synaptology@mail.ru

Eva Kudova

kudova@uochb.cas.cz

Received: 09 December 2019 Accepted: 04 March 2020

Published: 20 March 2020

Citation:

Bukanova JV, Solntseva El and Kudova E (2020) Neurosteroids as

Selective Inhibitors of Glycine Receptor Activity: Structure-Activity Relationship Study on Endogenous

Androstanes and Androstenes.

Front. Mol. Neurosci. 13:44.

doi: 10.3389/fnmol.2020.00044 inhibited I GABA. The threshold concentration of neurosteroids inducing effects on / Gly was $0.1 \mu \mathrm{M}$, and for effects on IGABA was 10-50 $\mu \mathrm{M}$. Moreover, our compounds accelerated desensitization of the $I_{\text {Gly }}$ with the $I_{50}$ values varying from 0.12 to $0.49 \mu \mathrm{M}$ and decreased the peak amplitude with $\mathrm{IC}_{50}$ values varying from 16 to $22 \mu \mathrm{M}$. Interestingly, our study revealed that only compounds 4 (epiandrosterone) and $\mathbf{8}$ (dehydroepiandrosterone) were able to cause a significant change in $I_{\text {GABA }}$ in $10 \mu \mathrm{M}$ concentration. Moreover, compounds $\mathbf{3}$ (testosterone), $\mathbf{5}$ (epitestosterone), $\mathbf{6}$ (dihydroandrostenedione), and $\mathbf{9}$ (etiocholanedione) did not modulate $I_{\text {GABA }}$ up to the concentration of $50 \mu \mathrm{M}$. Thus, we conclude that compounds $\mathbf{3}, \mathbf{5}, \mathbf{6}$, and $\mathbf{9}$ may be identified as selective modulators of $I_{\text {Gly }}$. Our results offer new avenues of investigation in the field of drug-like selective modulators of $I_{\text {Gly }}$.

Keywords: neurosteroid, GABA receptor, glycine receptor, androstane, androstene, structure-activity relationship

\section{INTRODUCTION}

$\gamma$-Aminobutyric acid receptors type A and glycine receptor $\left(\mathrm{GABA}_{\mathrm{A}} \mathrm{R}\right.$ and $\left.\mathrm{GlyR}\right)$ channels are the major inhibitory ligand-gated ion channels of the central nervous system which mediate both fast synaptic and tonic extrasynaptic inhibition (Lynch, 2009; Ziegler et al., 2009; Yevenes and Zeilhofer, 2011). Disturbance of functional activity of GlyRs and $G_{A B A}$ Rs underlies many neurological disorders. Dysfunction of $\mathrm{GABA}_{\mathrm{A}}$ Rs leads to channelopathies associated with epilepsy, insomnia, anxiety, and chronic pain (Möhler, 2006). Malfunctions of GlyR have been linked to a range of neurological disorders caused by mutations in genes which encode GlyR subunits, including hyperekplexia (mutations in the GlyR a1-subunit gene) (Lynch, 2004) or autism (mutations in the human GlyR $\alpha 2$-subunit gene) (Dougherty et al., 2013; Zhang et al., 2017). Finally, the $\alpha 3$ GlyRs 
have emerged as a promising therapeutic target for chronic pain, as the selective enhancement of the magnitude of the $\alpha 3$ GlyR current has been shown to exhibit analgesic effects in animal models of inflammatory pain (Lynch et al., 2017). In summary, diminished glycinergic inhibition (e.g., hyperekplexia, autism) would benefit most from facilitated glycinergic inhibition, through positive allosteric GlyR modulators. Interestingly, GlyRs modulation also plays a crucial role in synaptogenesis (Ganser and Dallman, 2009), neurite outgrowth (Tapia et al., 2000), or produces neuroprotection against metabolic stress such as oxygen/glucose deprivation (Tanabe et al., 2010). Given these considerations, GlyR-modulating compounds offer great potential for research on novel drug-like compounds.

The function of GlyRs can be modulated by various ligands, including neurosteroids (NS). Neurosteroids are compounds that accumulate in the nervous system independently of the steroidogenic endocrine glands and which can be synthesized de novo in the nervous system from cholesterol or other steroidal precursors imported from peripheral sources (Baulieu, 1998). The steroid numbering, ring letters, stereochemistry and nomenclature is summarized in Figure 1. The biosynthetic pathway (Do Rego et al., 2009) of NS (Figure 2) is triggered by the conversion of cholesterol to pregnenolone (PREG). Then, PREG is converted to progesterone (PROG) and dehydroepiandrosterone (DHEA). Subsequently, PROG is metabolized to $5 \alpha$ - or $5 \beta$-dihydroprogesterone, followed by their reduction to $3 \alpha$-hydroxy- $5 \alpha$-pregnan-20-one (allopregnanolone) or $3 \alpha$-hydroxy-5 $\beta$-pregnan-20-one (pregnanolone).

These compounds and their synthetic analogs are mainly known as potent modulators of $\mathrm{GABA}_{\mathrm{A}}$ Rs (Chen et al., 2019) and $N$-methyl- $D$-aspartate receptors (NMDARs) (Burnell et al., 2019), respectively. Neurosteroids and their synthetic analogs (neuroactive steroids, NAS) have been extensively studied during last three decades as they modify neuronal activity and thus brain function via a fast, non-genomic action (Rebas et al., 2017), by acting as allosteric modulators of various ligandgated ion channels, including $\mathrm{GABA}_{\mathrm{A}} \mathrm{R}$ and GlyR. In brief, NS and NAS are effective modulators of $\mathrm{GABA}_{\mathrm{A}} \mathrm{R}$-induced chloride current $\left(\mathrm{I}_{\mathrm{GABA}}\right)$ and their modulatory action is dependent on their structure and subtype (for a review, see: Majewska et al., 1988; Wu et al., 1990; Belelli and Lambert, 2005; Korinek et al., 2011; King, 2013; Zorumski et al., 2013). Those that potentiate GABA activity are termed as "potentiating NS" and these include, e.g., allopregnanolone ( $3 \alpha$-hydroxy-5 $\alpha$-pregnan-20-one) or pregnanolone ( $3 \alpha$-hydroxy-5 $\beta$-pregnan-20-one) (Park-Chung et al., 1999). The $\alpha$-configuration at C-3 is extremely important for potentiating steroids, contrasting with a relatively vague requirement for a $3 \alpha / 3 \beta$-configuration for "inhibitory NS" that are referred to as those that antagonize $I_{\mathrm{GABA}}$ (Park-Chung et al., 1999). The inhibitory NS incorporate mainly a subclass known as the C-3 sulfated steroids (e.g., pregnenolone sulfate and DHEA sulfate) (Gibbs et al., 2006) or the C-3 hemiester steroids (e.g., pregnanolone hemisuccinate) (Seljeset et al., 2015), although C-3 negative charge is not obligatory for the inhibition (e.g., DHEA). The relevance of configuration or double bond at C-5 for the potentiation/inhibitory action is driven by its combination with $\alpha / \beta$-configuration at C-3 (Park-Chung et al., 1999) that define a planar or "bent-shape" of the molecule (Figure 1E). Interestingly, the nature of the group at C-17, concerning inhibition, is less stringent given that 17-acetyl, 17-acetoxy, and 17-keto groups substituted onto a $3 \beta$-hydroxy-androst-5-ene retain similar inhibitory activities. On the other hand, 17-acetyl, 17-acetoxy, 17 -hydroxyl or 17 -keto groups substituted onto a $3 \alpha$-hydroxy$5 \alpha$-androstane exhibit markedly various enhancement of $I_{\mathrm{GABA}}$ varying up to 9-folds (Park-Chung et al., 1999). For example, the reduction of the C-20 ketone of $3 \alpha$-hydroxy- $5 \alpha$-pregnane20 -one to its $20 \alpha$-hydroxy analog greatly decreases the efficacy of potentiation $166 \%$ vs. $1373 \%$.

The GlyR-induced chloride current $\left(I_{\mathrm{Gly}}\right)$ has been also shown to be modulated by NS, but the data on potencies are rather limited to compounds with a pregnane skeleton (Figure 1F). Allopregnanolone (Figure 2) enhanced the glycineinduced current of native or recombinant receptors (Weir et al., 2004; Jiang et al., 2006), while Fodor et al. (2006) showed that micromolar concentrations of allopregnanolone blocked GlyRs of native cells. These variances may be ascribed to the difference between neuronal and recombinant GlyRs (Kung et al., 2001). Next, pregnanolone (Figure 2) proved to be an inhibitor of both $\alpha 1$ GlyRs and native cells (Weir et al., 2004; Fodor et al., 2006; Jiang et al., 2006). Finally, $3 \beta$-hydroxy-5 $\alpha$-pregnan-20-one and $3 \beta$-hydroxy-5 $\beta$-pregnan-20-one were demonstrated as inactive on both neurons and recombinant $\alpha 1$ receptors (Wu et al., 1990; Weir et al., 2004). Interestingly, PROG exhibited incomplete and non-competitive inhibition of GlyR currents in contrast to the full and competitive inhibition by its sulfated analog (PREG-S) of chick spinal cord (Wu et al., 1997) and selectively inhibited embryonic $\alpha 2$ GlyRs, with no effect on $\alpha 1$ and $\alpha 1 \beta$ GlyRs (Maksay et al., 2001). To date, only three androstane compounds were tested - DHEA sulfate and 3 $\beta$-hydroxy-5 $\alpha$-androstan-17-one, and $3 \alpha$-hydroxy-5 $\alpha$-androstan-17-one inhibited $I_{\mathrm{Gly}}$ currents in micromolar range on recombinant $\alpha 1$ receptors (Maksay et al., 2001). As such, the biological potential of androstane and androstene skeletons (Figure 1F) concerning their effect on GlyR remains unknown.

In our previous work, a series of pregnanolone derivatives (modulators of NMDA receptors) displayed the effects on the $I_{\mathrm{GABA}}$ and $I_{\mathrm{Gly}}$ in rat pyramidal hippocampal neurons (Bukanova et al., 2018). Interestingly, we demonstrated that the nature of the substituent at C-3 defines the positive or negative character of $I_{\mathrm{GABA}}$. Indeed, pregnanolone glutamate was found to potentiate $I_{\mathrm{GABA}}$, while pregnanolone hemisuccinate and pregnanolone hemipimelate inhibited $I_{\mathrm{GABA}}$, and all three steroids inhibited $I_{\mathrm{Gly}}$. The conversion of the $5 \beta$-pregnanolone skeleton into an $5 \beta$-androstane skeleton, an analog that lacks the C-17 acetyl moiety, eliminated the effects on both $\mathrm{GABA}_{\mathrm{A}}$ Rs and GlyRs.

As mentioned previously, the modulatory effect of NS on $\mathrm{GABA}_{\mathrm{A}} \mathrm{Rs}$ or GlyRs is a relevant avenue of investigation in neuropharmacology. To understand the structure-activity relationship of NS on $I_{\mathrm{GABA}}$ and $I_{\mathrm{Gly}}$, further structure-activity relationship studies (SAR) are required. In the present study, we examine the effects of a series of endogenous NS on the GABAand Gly-induced current in voltage-clamped rat cerebellar Purkinje cells and rat hippocampal neurons, respectively. This series contained 9 natural NS with an androstane and androstene 


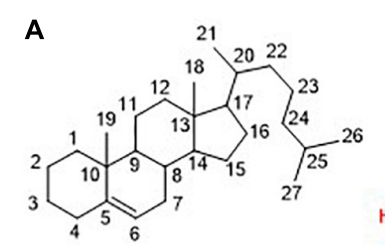

B

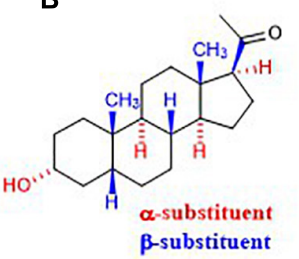

C<smiles>CC(C)CCC[C@@H]1CC[C@H]2[C@@H]3CC=C4CC(O)CC[C@]4(C)[C@H]3CC[C@]21C</smiles>

D<smiles>CC(C)CCC[C@H](C)[C@H]1CCC2C3CC=C4C[C@@H](O)CC[C@]4(C)C3CCC21C</smiles>

E

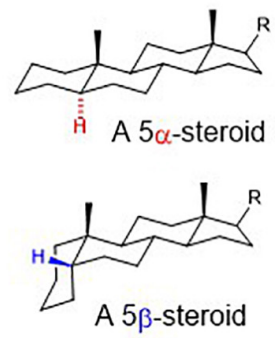

$\mathbf{F}$<smiles>CC12CCCC1C1CCC3CCCCC3(C)C1CC2</smiles>

Androstane<smiles>CC12CCCC1C1CCC3=CCCC[C@]3(C)C1CC2</smiles>

Androst-4-ene<smiles>CC[C@H]1CCC2C3CCC4CCCCC4(C)[C@H]3CC[C@]21C</smiles>

Pregnane<smiles>CC12CCCCC1=CCC1C3CCC[C@]3(C)C1CC2</smiles>

Androst-5-ene<smiles>CC(C)CCCC(C)[C@H]1CCC2C3CCC4CCCCC4(C)[C@@]3(C)CCC21C</smiles>

Cholestane<smiles>CC12CCCC1C1CC[C@H]3CCCC[C@]3(C)C1CC2</smiles>

$5 \alpha$-Androstane<smiles>CC12CCCC1C1CC[C@@]3(C)CCCC[C@]3(C)C1CC2</smiles>

$5 \beta$-Androstane

FIGURE 1 | (A) Steroid numbering and ring letters; (B) schematic orientation of substituents. When the rings of a steroid are denoted as projections onto the plane of the paper, the $\alpha$-substituent (hashed bond) lies below and the $\beta$-substituent (bold bond) lies above the plane of the paper; (C) explicitly written configuration for all sterocenters of cholesterol; (D) unless implied or stated to the contrary in figures and schemes, the stereochemistry of steroid molecule is simplified. Depicted structure implies that atoms or groups attached at the bridgehead positions $8,9,14$, and 17 are oriented as shown in formula $\mathrm{C}(8 \beta, 9 \alpha, 14 \alpha)$. Angular methyles $\left(\mathrm{CH}_{3}\right)$ at positions 10, 13 are omitted and shown only as bold bonds; (E) a perspective representation of planar $5 \alpha$-steroid and a bent molecule of $5 \beta$-steroid; (F) fundamental names of steroid skeletons relevant to this paper.

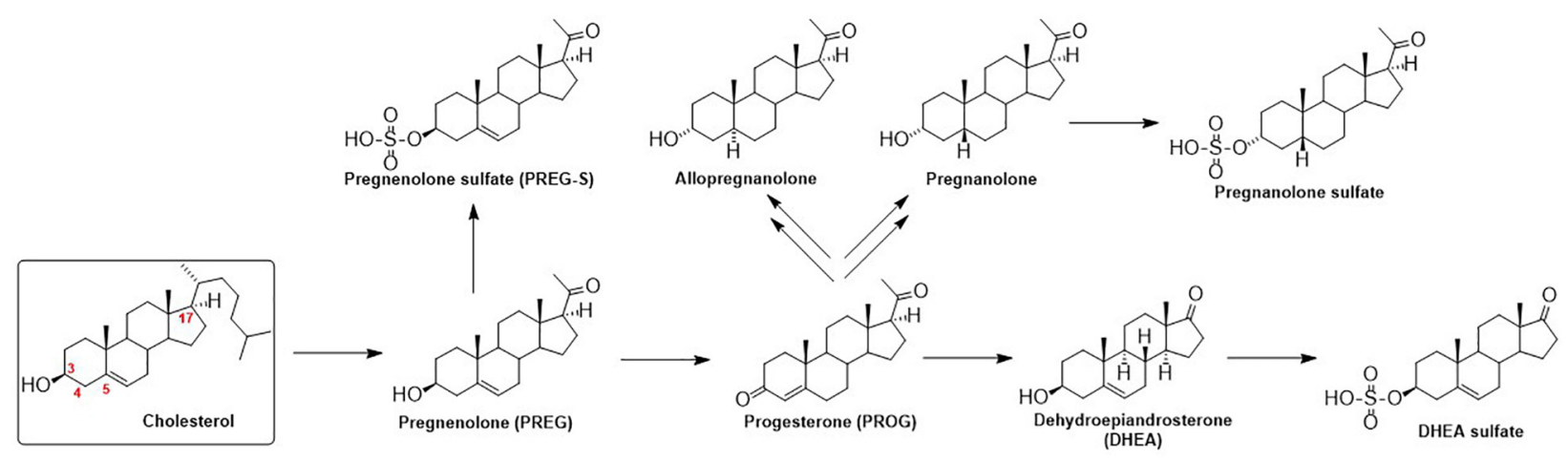

FIGURE 2 | Schematic illustration of neurosteroid biosynthesis.

skeleton with variable substituents at C-3, C-5, and C-17 positions (Table 1).

\section{MATERIALS AND METHODS}

\section{Cell Preparation}

All experiments were conducted per the requirements of the Ministry of Public Health of the Russian Federation and were consistent with the EU directive for Use of Experimental Animals of the European Community. The study was approved by the Ethics Committee of the Scientific Center of Neurology, Protocol No. 2-5/19 of 02.20.19. The cells were isolated from transverse hippocampal slices as described in detail elsewhere
(Vorobjev, 1991). Briefly, the slices (200-500 $\mu \mathrm{m}$ ) of Wistar rats (11-14 days of age) hippocampus or cerebellum were incubated at room temperature for at least $2 \mathrm{~h}$ in a solution containing the following components (in $\mathrm{mM}$ ): $124 \mathrm{NaCl}, 3 \mathrm{KCl}$, $2 \mathrm{CaCl}_{2}, 2 \mathrm{MgSO}_{4}, 25 \mathrm{NaHCO}_{3}, 1.3 \mathrm{NaH}_{2} \mathrm{PO}_{4}, 10$ D-glucose, $\mathrm{pH}$ 7.4. The saline was continuously stirred and bubbled with carbogen $\left(95 \% \mathrm{O}_{2}+5 \% \mathrm{CO}_{2}\right)$. Single pyramidal neurons from the hippocampal CA3 area or Purkinje cells from sagittal slices of the cerebellum were isolated by a vibrating fused glass pipette with a spherical tip.

\section{Current Recordings}

Isolated neurons were patch clamped and then lifted into the outflow of the control bath solution. Bath solution flowed 
TABLE 1 | Structure-activity relationship study overview for compounds 1-9: their chemical names, structures, $\tau_{\text {des }}\left(I_{\text {Gly }}\right.$ vs. $\left.I_{\text {GABA }}\right)$ values.

\begin{tabular}{|c|c|c|c|c|c|}
\hline \multirow[t]{2}{*}{ Cmpd. } & \multirow[t]{2}{*}{ Chemical name } & \multirow[t]{2}{*}{ Common name } & \multirow[t]{2}{*}{ Structure } & \multicolumn{2}{|c|}{${ }^{\mathrm{a}} \tau_{\text {des }}$} \\
\hline & & & & $I_{\mathrm{Gly}}$ & $I_{\mathrm{GABA}}$ \\
\hline 1 & 17 $\beta$-Hydroxyandrost-4-en-3-one & Testosterone & & $-67 \%$ & ${ }^{\mathrm{b}} \mathrm{No}$ effect \\
\hline 2 & Androst-4-en-3,17-dione & Androstenedione & & $-84 \%$ & ${ }^{b}$ No effect \\
\hline 3 & $17 \beta$-Hydroxy-5 $\alpha$-androstan-3-one & $5 \alpha$ - Dihydrotestosterone & & $-82 \%$ & ${ }^{\mathrm{c}}$ No effect \\
\hline 4 & $3 \beta$-Hydroxy-5 $\alpha$-androstan-17-one & Epiandrosterone & & $-64 \%$ & $-20 \%$ \\
\hline 5 & $17 \alpha$-Hydroxyandrost-4-en-3-one & Epitestosterone & & $-72 \%$ & ${ }^{\mathrm{c}} \mathrm{No}$ effect \\
\hline 6 & $5 \alpha$-Androstane-3,17-dione & Dihydroandrostenedione & & $-72 \%$ & ${ }^{\mathrm{c} N o}$ effect \\
\hline 7 & $3 \beta, 17 \beta$-Androst-5-ene-3,17-diol & Androstenediol & & $-70 \%$ & ${ }^{\mathrm{b}}$ No effect \\
\hline 8 & 3ß-Hydroxy-androst-5-en-17-one & Dehydroepiandrosterone (DHEA) & & $-79 \%$ & $-12 \%$ \\
\hline 9 & $5 \beta$-Androstane-3,17-dione & Etiocholanedione & & $-68 \%$ & ${ }^{\mathrm{C}}$ No effect \\
\hline
\end{tabular}

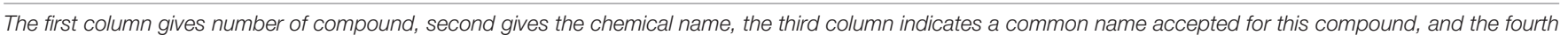

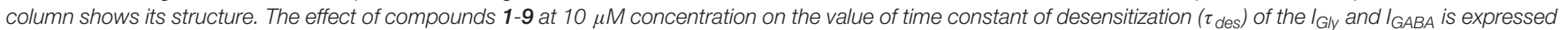

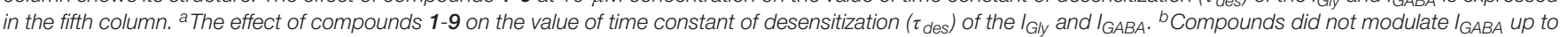
the concentration of $10 \mu \mathrm{M} .{ }^{C}$ Compounds did not modulate IGABA up to the concentration of $50 \mu \mathrm{M}$.

through a tube with a diameter of $1.5 \mathrm{~mm}$ at a speed of $0.6 \mathrm{ml} / \mathrm{min}$. The substances were applied through glass capillary, $0.1 \mathrm{~mm}$ in diameter, which could be rapidly displaced laterally (Vorobjev et al., 1996). A fast perfusion technique allows a complete exchange of external solution surrounding a neuron within $20 \mathrm{~ms}$. Glycine-activated currents $\left(I_{\mathrm{Gly}}\right)$ and GABA-activated currents $\left(I_{\mathrm{GABA}}\right)$ in isolated neurons were induced by a step application of agonist for 600-1000 ms with 30-40 s intervals. Transmembrane currents were recorded using a conventional patch-clamp technique in the whole-cell configuration. Patch-clamp electrodes had a tip resistance of $\sim 2 \mathrm{M} \Omega$. The solution in the recording pipette contained the following (in mM): $40 \mathrm{CsF}, 100 \mathrm{CsCl}, 0.5 \mathrm{CaCl}_{2}, 5 \mathrm{EGTA}$, $3 \mathrm{MgCl}_{2}, 4 \mathrm{NaATP}, 5$ HEPES, $\mathrm{pH}$ 7.3. The composition of the extracellular solution was as follows (in $\mathrm{mM}$ ): $140 \mathrm{NaCl}$,
$3 \mathrm{KCl}, 3 \mathrm{CaCl}_{2}, 3 \mathrm{MgCl}_{2}, 10 \mathrm{D}$-glucose, $10 \mathrm{HEPES}$ hemisodium, and $\mathrm{pH}$ 7.4. Recording of the currents was performed using EPC7 patch-clamp amplifier (HEKA Electronik, Germany). The holding potential was maintained at $-70 \mathrm{mV}$. Transmembrane currents were filtered at $3 \mathrm{kHz}$, stored and analyzed with IBM-PC computer, using homemade software.

\section{Reagents}

All the drugs used for intracellular and extracellular solutions were purchased from Sigma-Aldrich (United States). Compounds 1-9 are available from Sigma-Aldrich or Carbosynth under the following CAS and catalog numbers: compound $\mathbf{1}$ (Sigma, CAS 58-22-0, Cat. No. T1500), compound 2 (Sigma, CAS 63-05-8, Cat. No. 46033), compound 3 (Sigma, CAS 521-18-6, Cat. No. A8380), compound 4 (Sigma, CAS 481-29-8, Cat. No. 
E3375), compound 5 (Sigma, CAS 481-30-1, Cat. No. 1646031), compound 8 (CAS 53-43-0, Cat No. D4000). Compound 7 (CAS 521-17-5) was prepared by sodium borohydride reduction from compound $\mathbf{8}$ according to the literature (Liu et al., 2012). Compound 6 (CAS 846-46-8) and compound 9 (CAS 122912-5) were prepared by Jones oxidation from compound 5 and $3 \alpha$-hydroxy-5 $\beta$-androstan-17-one (Sigma, CAS 53-42-9, Cat. No. E5126), respectively, according to the literature (Katona et al., 2008). The purity of all used steroids was $>95 \%$. The tested substances were dissolved in $100 \%$ DMSO to make $10 \mathrm{mM}$ stock solution, which was aliquoted and stored at $-20^{\circ} \mathrm{C}$. Then, drugs were dissolved in external saline to the final concentrations immediately before the experiments. The maximal percentage of solvent in the tested drug solutions was $1 \%$. The $I_{\mathrm{Gly}}$ and $I_{\mathrm{GABA}}$ were measured in the presence of $1 \%$ DMSO $(n=6)$, and any current changes was not found under these conditions.

\section{Data Analysis}

Statistical analysis was performed with the help of Prism Graphpad software. All comparisons were made with ANOVAtest using Dunnett's multiple comparison test and Student's unpaired $t$-test at a significance level of $p=0.05$. $N=5-8$ cells from 3 to 4 animals for every concentration. In results descriptions, mean and standard error of the mean (SEM) are specified. The meanings of asterisks (probability levels) in figures is the following: ${ }^{*} P<0.05,{ }^{*} P<0.01$. The $\mathrm{IC}_{50}$ values for steroids inhibition of the $I_{\mathrm{Gly}}$ and $I_{\mathrm{GABA}}$ were determined using the equation: $\mathrm{Y}=1-\left[\mathrm{max} /\left(1+\left(\mathrm{IC}_{50} / \mathrm{C}\right)^{n}\right)\right]$, where $\max$ is the maximum inhibition attainable, $C$ is the concentration of steroid, $\mathrm{IC}_{50}$ is the half-maximal inhibitory concentration and $n$ is the slope factor (Hill coefficient).

\section{RESULTS}

\section{Effect of Neurosteroids 1-9 on the $I_{\text {Gly }}$ and I IGAB}

The effects of compounds 1-9 (Table 1) were studied at a concentration range of $0.01-100 \mu \mathrm{M}$ on isolated rat hippocampal neurons and rat cerebellar Purkinje cells. First, the ability of steroids to affect the holding current at voltage-clamp regime was tested. We have found that compounds 1-9 by themselves did not cause any currents through the cell membrane (data not shown). Next, the influence of compounds 1-9 on glycineactivated chloride current $\left(I_{\mathrm{Gly}}\right)$ and GABA-activated chloride current $\left(I_{\mathrm{GABA}}\right)$ were evaluated. The experiments with $I_{\mathrm{Gly}}$ were conducted on rat hippocampal neurons, and experiments with $I_{\mathrm{GABA}}$ were conducted on rat cerebellar Purkinje cells. The $I_{\mathrm{Gly}}$ is larger in amplitude and more stable on hippocampal cells, and, conversely, the $I_{\mathrm{GABA}}$ is more convenient to study on Purkinje cells, since GABA receptors on Purkinje cells are more homogeneous (Kelley et al., 2013). Glycine (100 $\mu \mathrm{M})$ and GABA (5 $\mu \mathrm{M})$ were applied to the neurons through an application pipette during 600-1000 ms and compounds 1-9 were added to the same pipette in different concentrations $(0.01-100 \mu \mathrm{M})$. Our experiments demonstrate that neuronal GlyRs are highly sensitive, whilst neuronal $\mathrm{GABA}_{\mathrm{A}}$ Rs are weakly sensitive to tested compounds 1-9.

\section{Effects of Compounds 1-9 on the $I_{\text {Gly }}$}

Short (600-1000 ms) application of $100 \mu \mathrm{M}$ glycine on pyramidal neurons of rat hippocampus evoked $I_{\mathrm{Gly}}$ which amplitude and kinetics were dependent on glycine concentration with an $\mathrm{EC}_{50}$ value of $90 \pm 7 \mu \mathrm{M}$. An average value of the reversal potential of $I_{\mathrm{Gly}}-9.6 \pm 0.8 \mathrm{mV}$ matched well the chloride reversal potential calculated for the chloride concentrations used $(-9.5 \mathrm{mV}$, not shown). We used agonist concentration of $100 \mu \mathrm{M}$ that was near $\mathrm{EC}_{50}$, because it allow to achieve stable current with well visible and measurable either suppressive or augmenting effect. All 9 compounds caused a similar effect on the $I_{\mathrm{Gly}}$, which consisted of two components: acceleration of desensitization and decrease in peak amplitude. The effects were reversible upon washout during 1-2 min. The effect of desensitization acceleration developed at significantly lower concentrations of NS than the effect of peak amplitude suppression. Noteworthy, the threshold concentration of NS for initiating the effect of desensitization acceleration was $0.1 \mu \mathrm{M}$, while the threshold concentration of the same compounds for developing the effect of the peak amplitude reduction was $10 \mu \mathrm{M}$. A representative effect of NS on $I_{\mathrm{Gly}}$ of one cell is shown in Figure 3A. Compound $\mathbf{1}$ in low concentrations of 0.1 and $1 \mu \mathrm{M}$ accelerated desensitization without effect on the peak amplitude, while at a concentration of 10 and 100 $\mu \mathrm{M}$ it causes two effects: acceleration of desensitization and a decrease in peak amplitude. The effects of the remaining eight NS on the $I_{\mathrm{Gly}}$ did not differ significantly from the testosterone effect (for details, see Figures 3B,C and Table 2). When coapplied with glycine, NS at concentration $0.1 \mu \mathrm{M}$ barely affected the $I_{\mathrm{Gly}}$ peak amplitude but decreased the time constant of $I_{\mathrm{Gly}}$ desensitization $\left(\tau_{\mathrm{des}}\right)$ by $27-35 \%(P<0.01$ or $P<0.05)$. On the contrary, when applied at a concentration of $10 \mu \mathrm{M}$, NS accelerated desensitization by $67-82 \%(P<0.01)$ and reduced the peak current amplitude by $18-25 \%(P<0.01$ or $P<0.05)$. Figure 4 shows the concentration dependence of the NS effect on the normalized peak amplitude (Figure 4A) and normalized $\tau_{\text {des }}$ of the $I_{\text {Gly }}$ (Figure $4 \mathrm{C}$ ). An increase in the concentration of NS up to $100 \mu \mathrm{M}$ caused a decrease in the peak amplitude of the $I_{\mathrm{Gly}}$ by $45-70 \%$ with the $\mathrm{IC}_{50}$ values of $16-22 \mu \mathrm{M}$ (Figure $4 \mathrm{~B}$ and Table 3). Maximal decrease (70-90\%) of the $\tau_{\text {des }}$ can be observed in the presence of $10 \mu \mathrm{M}$ of NS. The $\mathrm{IC}_{50}$ values for the effect on the $\tau_{\text {des }}$ are in the range of $0.12-0.49 \mu \mathrm{M}$ (Figures 4C,D and Table 3), which are two orders of magnitude lower than the $\mathrm{IC}_{50}$ values for the effect on peak amplitude.

\section{Effects of Compounds 1-9 on the IGABA}

The brief application of GABA for $600-1000 \mathrm{~ms}$ on isolated Purkinje cells evoked a chloride current $\left(I_{\mathrm{GABA}}\right)$ with an amplitude-dependent on GABA concentration with an $\mathrm{EC}_{50}$ value of $7.5 \pm 2.9 \mu \mathrm{M}$. The specific antagonist of $\mathrm{GABA}_{\mathrm{A}}$ receptors bicuculline $(3 \mu \mathrm{M})$ reversibly blocked the current (data not shown), which allows us to classify the receptors as $\mathrm{GABA}_{\mathrm{A}}$ type. We studied $I_{\mathrm{GABA}}$ evoked by $5 \mu \mathrm{M}$ of GABA. Figure 5 shows the effects of NS on $I_{\mathrm{GABA}}$. Our experiments demonstrate that $\mathrm{GABA}_{\mathrm{A}}$ Rs are much less sensitive to the studied NS than 


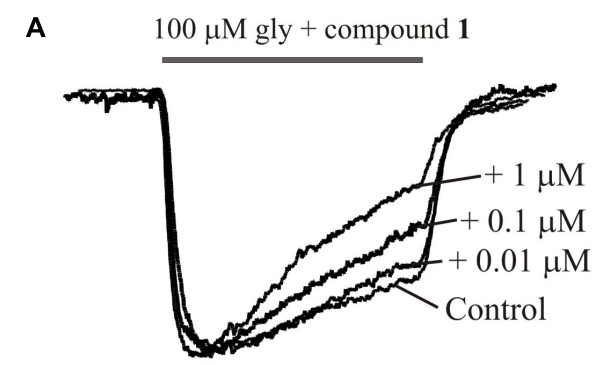

B

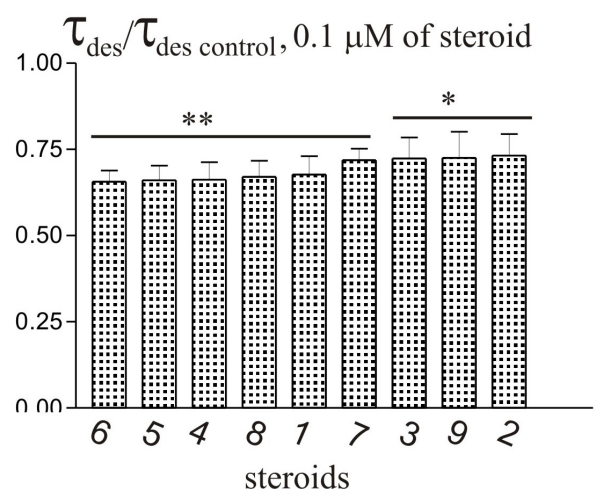

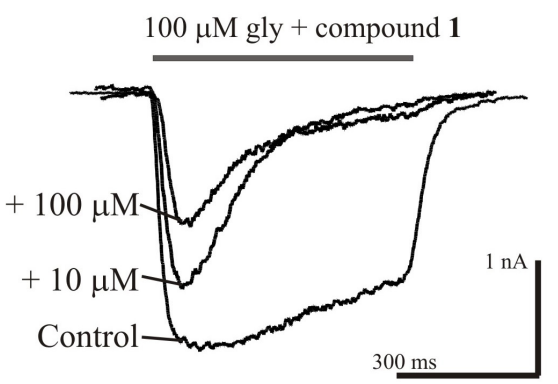

C

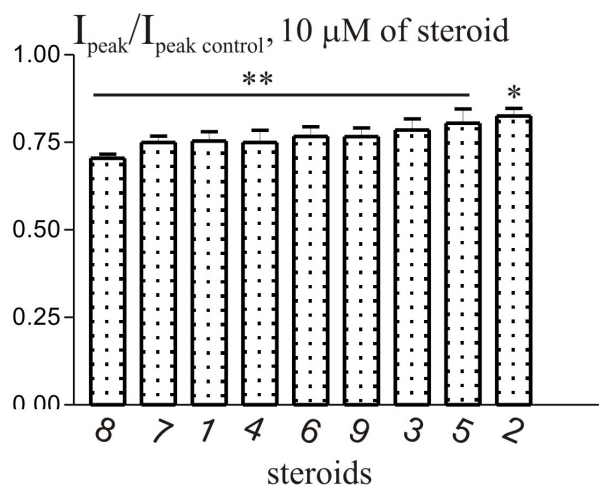

FIGURE 3 | The effects of compounds 1-9 on / Gly of hippocampal neurons. (A) Representative traces of $I_{\text {Gly }}$ induced by 600 ms application of $100 \mu$ M glycine, obtained in control and the presence of $0.01,0.1$, and $1 \mu \mathrm{M}$ (left), or 10 and $100 \mu \mathrm{M}$ (right) of testosterone (compound $\mathbf{1}$ ). (B) Mean \pm SEM of the normalized values of the time constant of desensitization ( $\tau_{\text {des }}$ ) of $I_{\text {Gly }}$ in the presence of $0.1 \mu \mathrm{M}$ of compounds 1-9. (C) Mean \pm SEM of the normalized values of the peak amplitude of $I_{\text {Gly }}$ in the presence of $10 \mu \mathrm{M}$ of compounds 1-9. Results show greater action of NS on desensitization than on peak amplitude of $I_{\text {Gly }}$. Probability levels were estimated with ANOVA-test using Dunnett's multiple comparison test.

GlyRs. The addition of compounds $1,2,3,5,7,9$ to the applicator pipette at a concentration of $0.1-10 \mu \mathrm{M}$ did not change either the peak amplitude or the rate of decay of $I_{\mathrm{GABA}}$. Only two out of nine compounds - compounds 4 and 8 - in $10 \mu \mathrm{M}$ concentration were able to cause a significant change in $I_{\mathrm{GABA}}$, which consisted

TABLE 2 | The inhibitory effect of the tested neurosteroids on the time constant of desensitization ( $\left.\tau_{\text {des }}\right)$ and peak amplitude ( $\left.I_{\text {peak }}\right)$ of the $I_{\text {Gly }}$. Mean \pm SEM of the normalized values of the $\tau_{\text {des }}$ and $I_{\text {peak }}$ of the $I_{\text {Gly }}$ are shown.

\begin{tabular}{lcccccc}
\hline Cmpd. & $\begin{array}{c}\boldsymbol{\tau}_{\text {des }} / \tau_{\text {des control }}, \\
\mathbf{0 . 1} \boldsymbol{\mu} \mathbf{M} \text { of steroid }\end{array}$ & $\boldsymbol{P}$-value & $\mathbf{n}$ & $\begin{array}{c}\mathbf{I}_{\text {peak }} / \mathbf{I}_{\text {peak control }} \\
\mathbf{1 0} \boldsymbol{\mu} \mathbf{M} \text { of steroid }\end{array}$ & $\boldsymbol{P}$-value & $\mathbf{n}$ \\
\hline 1 & $0.68 \pm 0.05$ & 0.0055 & 5 & $0.75 \pm 0.03$ & 0.0006 & 7 \\
2 & $0.73 \pm 0.06$ & 0.0199 & 5 & $0.82 \pm 0.02$ & 0.0199 & 7 \\
3 & $0.72 \pm 0.06$ & 0.0186 & 5 & $0.78 \pm 0.03$ & 0.0037 & 8 \\
4 & $0.66 \pm 0.05$ & 0.0033 & 5 & $0.75 \pm 0.03$ & 0.0023 & 7 \\
5 & $0.66 \pm 0.04$ & 0.0014 & 7 & $0.80 \pm 0.04$ & 0.0181 & 7 \\
6 & $0.65 \pm 0.03$ & 0.0002 & 8 & $0.76 \pm 0.03$ & 0.0011 & 8 \\
7 & $0.72 \pm 0.03$ & 0.0013 & 8 & $0.75 \pm 0.02$ & 0.0004 & 7 \\
8 & $0.67 \pm 0.05$ & 0.0027 & 5 & $0.70 \pm 0.01$ & 0.0003 & 7 \\
9 & $0.72 \pm 0.07$ & 0.0358 & 5 & $0.77 \pm 0.03$ & 0.0006 & 7
\end{tabular}

All comparisons with control value were made with unpaired Student's t-test. Significance level of $P=0.05$. $n$ - the number of cells used. of the acceleration of decay (Figures 5A,B and Table 4). When the concentration of the tested compound was increased up to $50 \mu \mathrm{M}$, compounds $\mathbf{3}, \mathbf{5}, \mathbf{6}$, and 9 remained inactive. In contrast, compounds $1,2,4,7$, and 8 at $50 \mu \mathrm{M}$ concentration showed an inhibitory effect with a decrease in the peak amplitude of the current by $14-25 \%(P<0.01$ or $P<0.05)$ and the acceleration of its decay by $23-45 \%(P<0.01)$ (Figure 5 and Table 4). Figure 6 shows a comparison of the effects of compounds 1-9 on the $I_{\mathrm{Gly}}$ and the $I_{\mathrm{GABA}}$. Our results demonstrate that tested NS in the concentration of $10 \mu \mathrm{M}$ cause strong action on $I_{\mathrm{Gly}}$ and weak action on $I_{\mathrm{GABA}}$.

\section{DISCUSSION}

In the present study, we examined the effects of a series of endogenous NS on the GABA- and Gly-induced current in rat central neurons. It is known that NS modulate $\mathrm{GABA}_{\mathrm{A}} \mathrm{Rs}$ and GlyRs functions in subunit-specific manner (Maksay et al., 2001; Belelli and Lambert, 2005) and this has implications for native receptors that may differentiate throughout development. We used in our experiments Wistar rats at 11-14 days of age where GlyRs and $\mathrm{GABA}_{\mathrm{A}}$ Rs were studied in pyramidal hippocampal neurons and cerebellar Purkinje cells, accordingly. Literature 
A

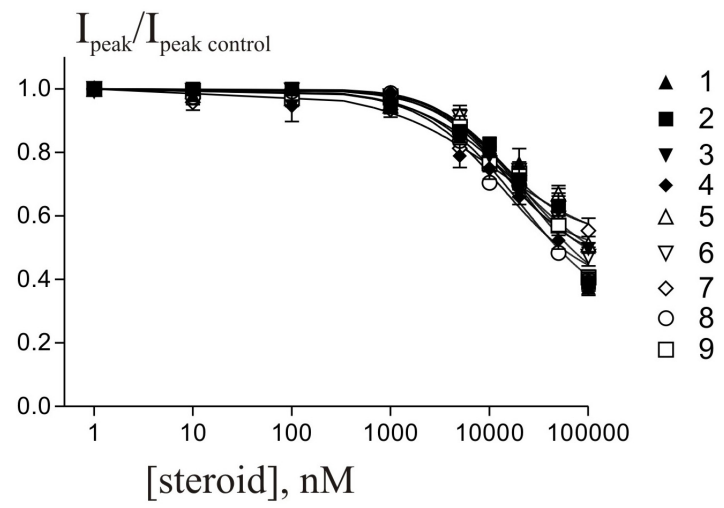

C
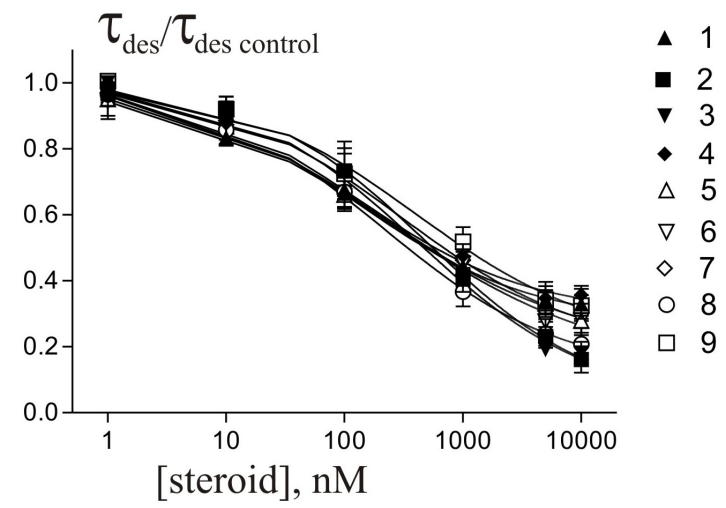

B

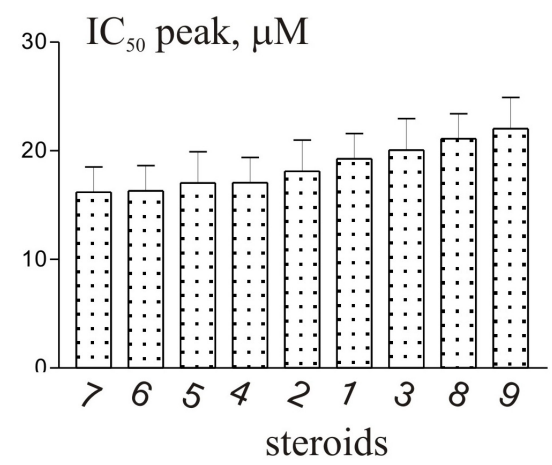

D

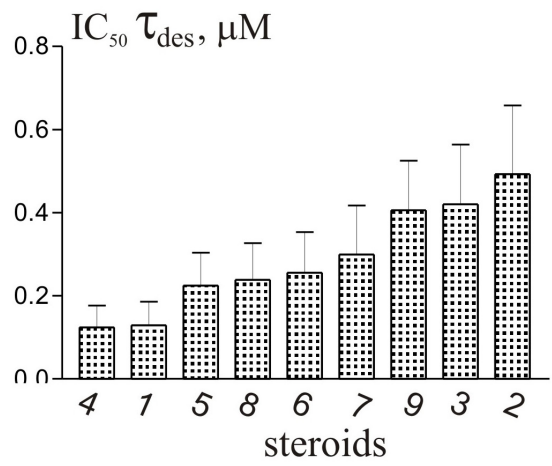

FIGURE 4 | Concentration dependence of NS effects on the $I_{\text {Gly }}$ of hippocampal neurons. (A) Concentration dependence of compounds 1-9 effect on the normalized peak amplitude of $I_{\text {Gly }}$. Data were fitted with the Hill equation (see section Materials and Methods). (B) Mean \pm SEM of the $I C_{50}$ values calculated for the effect of inhibition by NS of the peak amplitude of $I_{\text {Gly }}$ (C) Concentration dependence of compounds 1-9 effect on the normalized $\tau_{\text {des }}$ of $I_{\text {Gly }}$. Data were fitted with the Hill equation. (D) Mean $\pm \mathrm{SEM}$ of the $\mathrm{IC}_{50}$ values calculated for the effect of accelerating desensitization (decrease in the $\tau_{\text {des }}$ ) of $I_{\text {Gly }}$ by $N S$.

TABLE 3 | The values of the maximum inhibition attainable (max), the half-maximal inhibitory concentration $\left({ }^{\left(C_{50}\right)}\right.$ and the slope factor (Hill coefficient) for the effects of tested steroids on the peak amplitude $\left(I_{\text {peak }}\right)$ and $\tau_{\text {des }}$ of the $I_{\text {Gly }}$.

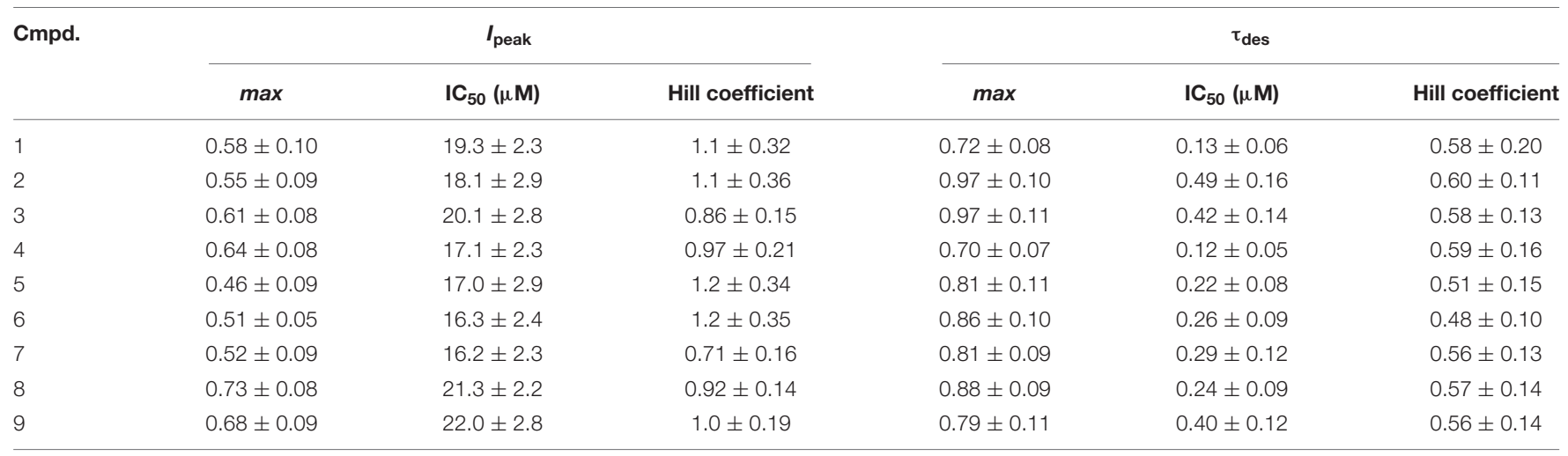

The fits were made to the averaged data with the fitting program.

data indicate that starting from the second postnatal week, the subunit composition of GlyR in the hippocampal neurons (Aroeira et al., 2011) and $\mathrm{GABA}_{\mathrm{A}} \mathrm{R}$ in the Purkinje cells of the cerebellum (Laurie et al., 1992) is close to that in the brain of adult animals. Extrasynaptic GlyRs with different subunit composition are described in pyramidal hippocampal neurons. There may be either heteromeric receptors with $\alpha(1,2$, or 3$)$ and $\beta$ subunits, or homomeric ones with multiple $\alpha$ subunits (for review, see Keck and White, 2009; Xu and Gong, 2010). The major adult isoform of $\mathrm{GABA}_{A}$ Rs in Purkinje cells was shown to be composed of $\alpha_{1} \beta_{2} \gamma_{2}$ 

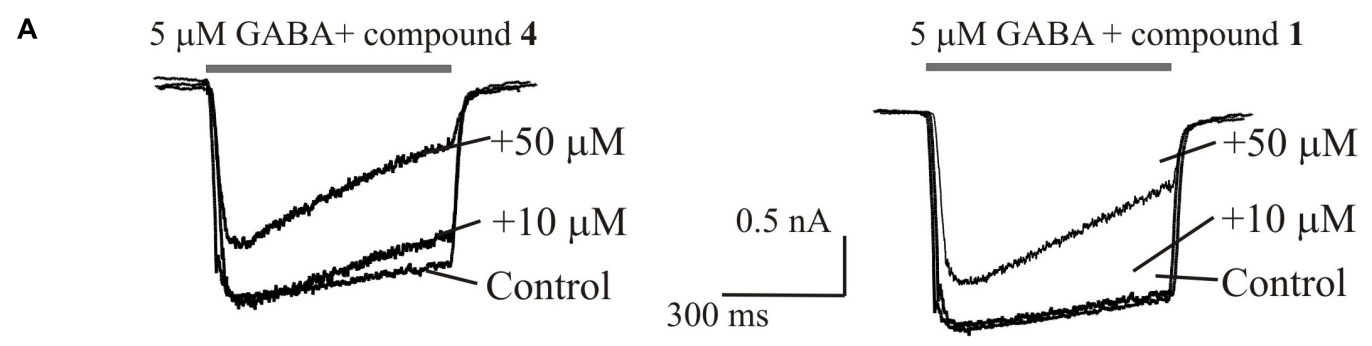

B

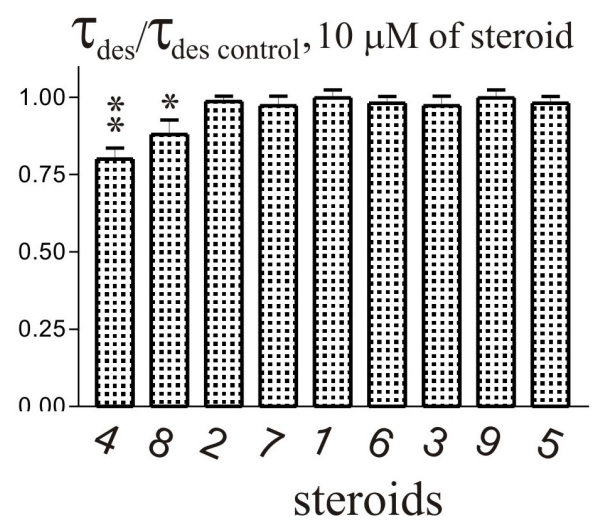

C

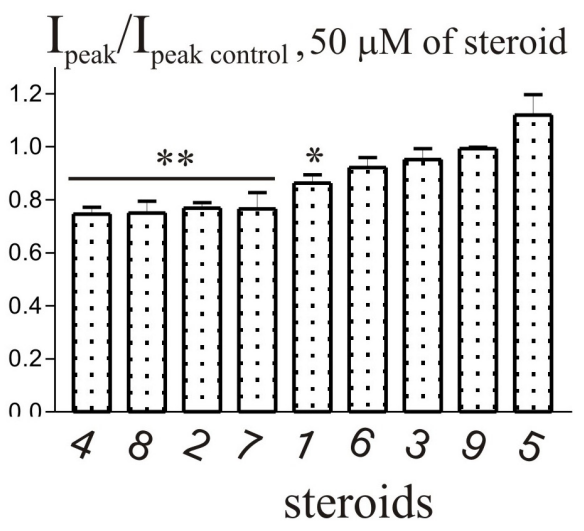

FIGURE 5 | The effects of compounds 1-9 on /GABA of cerebellar Purkinje cells. (A) Representative traces of $I_{\text {GABA }}$ induced by 600 ms application of $5 \mu M$ GABA, obtained in control and the presence of 10 and $50 \mu \mathrm{M}$ of compound $\mathbf{4}$ (epiandrosterone) (left), or compound $\mathbf{1}$ (testosterone) (right). (B) Mean \pm SEM of the normalized values of the time constant of desensitization ( $\left.\tau_{\text {des }}\right)$ of $I_{G A B A}$ in the presence of $10 \mu \mathrm{M}$ of compounds 1-9. (C) Mean \pm SEM of the normalized values of the peak amplitude of $I_{\text {GABA }}$ in the presence of $50 \mu \mathrm{M}$ of compounds 1-9. Probability levels were estimated with ANOVA-test using Dunnett's multiple comparison test.

subunits and with a subunit stoichiometry of 2:2:1 (Pirker et al., 2000; Sieghart and Savić, 2018).

The series of steroids we studied included endogenous androstane and androstene NS (compounds 1-9) with variable substituents at positions C-3, C-5, and C-17 (Table 1). In brief,

TABLE 4 | The inhibitory effect of the tested neurosteroids on the peak amplitude (I peak $)$ and time constant of desensitization ( $\left.\tau_{\text {des }}\right)$ of the $I_{\text {GABA }}$.

\begin{tabular}{lcccccc}
\hline Cmpd. & $\begin{array}{c}\boldsymbol{\tau}_{\text {des }} / \tau_{\text {des control }} \\
\mathbf{1 0} \boldsymbol{\mu} \mathbf{M} \text { of steroid }\end{array}$ & $\boldsymbol{P}$-value & $\boldsymbol{n}$ & $\begin{array}{c}\mathbf{I}_{\text {peak }} / \mathbf{I}_{\text {peak control }} \\
\mathbf{5 0} \boldsymbol{\mu} \mathbf{M} \text { of steroid }\end{array}$ & $\boldsymbol{P}$-value & $\boldsymbol{n}$ \\
\hline 1 & $0.99 \pm 0.02$ & 0.8273 & 5 & $0.86 \pm 0.03$ & 0.0040 & 8 \\
2 & $0.98 \pm 0.02$ & 0.4625 & 6 & $0.77 \pm 0.02$ & 0.0001 & 7 \\
3 & $0.98 \pm 0.02$ & 0.5264 & 6 & $0.95 \pm 0.03$ & 0.2608 & 6 \\
4 & $0.80 \pm 0.03$ & 0.0014 & 6 & $0.75 \pm 0.03$ & 0.0001 & 7 \\
5 & $0.97 \pm 0.03$ & 0.4228 & 6 & $1.12 \pm 0.08$ & 0.2069 & 8 \\
6 & $0.99 \pm 0.02$ & 0.8273 & 5 & $0.92 \pm 0.04$ & 0.0926 & 7 \\
7 & $0.98 \pm 0.02$ & 0.4626 & 5 & $0.77 \pm 0.06$ & 0.0055 & 7 \\
8 & $0.88 \pm 0.05$ & 0.0265 & 6 & $0.75 \pm 0.04$ & 0.0005 & 8 \\
9 & $0.97 \pm 0.03$ & 0.4228 & 5 & $0.99 \pm 0.01$ & 0.5690 & 8 \\
\hline
\end{tabular}

Mean $\pm S E M$ of the normalized values of the $\tau_{\text {des }}$ and $I_{\text {peak }}$ of the $I_{\text {GABA }}$ are shown. All comparisons with control value were made with unpaired Student's t-test. Significance level of $P=0.05 . n$ - the number of cells used. compounds $1,3,7$, and 5 bear $17 \beta$ - and $17 \alpha$-hydroxyl groups, respectively. Compounds 2, 4, 6, 8, and 9 have a carbonyl group at C-17. Compounds 1, 2, 5, 7, and 8 have a double bond in their skeleton and as such belong to a family of androstene steroids. Oppositely, compounds 3, 4, $6(5 \alpha-\mathrm{H})$, and $9(5 \beta-\mathrm{H})$ are fully saturated androstanes. The results of our study show that biological activity is similar for all compounds. In summary, compounds 1-9 at a concentration up to $10 \mu \mathrm{M}$ strongly affected $I_{\mathrm{Gly}}$ and had weak action on $I_{\mathrm{GABA}}$. The effect of NS on $I_{\mathrm{Gly}}$ contained two components: a decrease in peak amplitude and an acceleration of decay. The effect of NS on $I_{\text {Gly }}$ decay and the associated decrease in time constant of desensitization $\left(\tau_{\text {des }}\right)$ was $2-3$ times stronger than on the peak of $I_{\mathrm{Gly}}$. Such a different regulation of these two $I_{\mathrm{Gly}}$ parameters by NS suggests the existence of two independent mechanisms of their action on GlyRs, one of which regulates the peak amplitude, and the second - the desensitization process. This assumption is supported by our previous research (Bukanova et al., 2018), where it was shown that these two effects of NS afford different outcome with increasing glycine concentration. Namely, the effect on the peak amplitude of $I_{\text {Gly }}$ disappeared and the acceleration of desensitization remained. The fact that peak inhibition is reduced at higher agonist concentration suggest that inhibiting drugs act as competitive inhibitors of agonist 
A

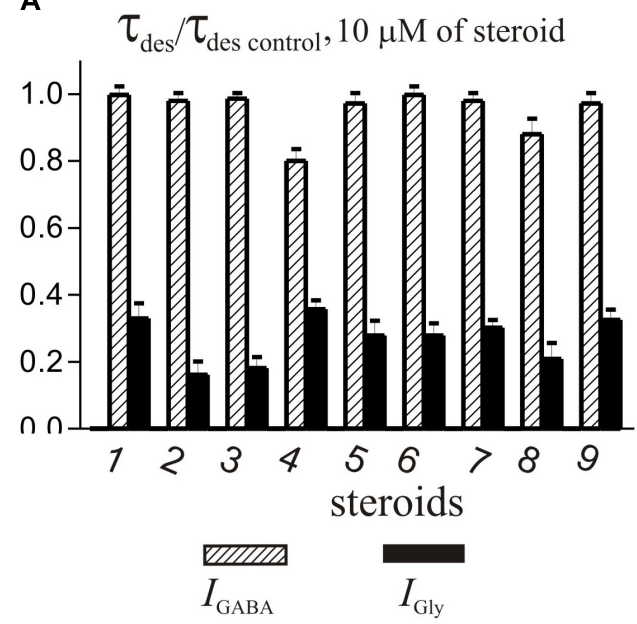

B

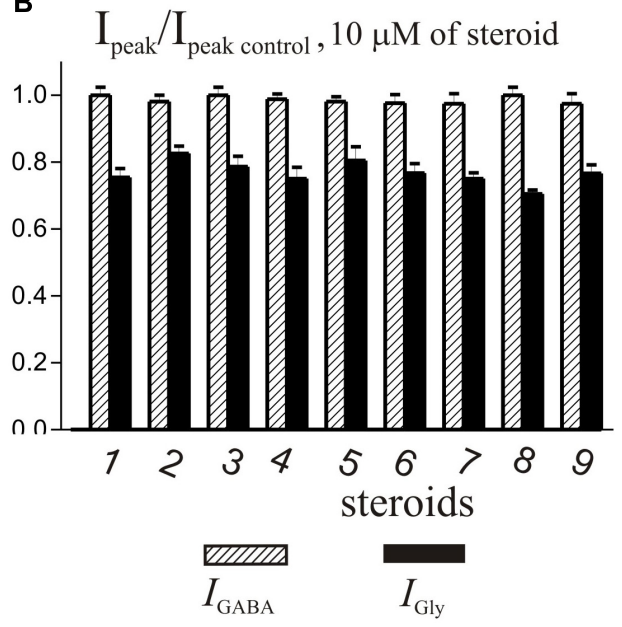

FIGURE 6 | Comparison of the effects of NS on $I_{\text {Gly }}$ and the $I_{\text {GABA }}$ (A) Mean \pm SEM of the normalized values of the time constant of desensitization ( $\tau_{\text {des }}$ ) of $I_{\text {GABA }}$ (shaded columns) and $I_{\text {Gly }}$ (black columns) in the presence of $10 \mu \mathrm{M}$ of compounds 1-9. (B) Mean \pm SEM of the normalized values of the peak amplitude of $I_{\text {GABA }}$ (shaded columns) and $I_{\text {Gly }}$ (black columns) in the presence of $10 \mu \mathrm{M}$ of compounds 1-9. Results show greater action of all nine compounds on the $I_{\text {Gly }}$ than on the $I_{\text {GABA }}$

binding or that the inhibitors preferentially bind to resting states of the receptor (Li et al., 2007). However, the effect of NS on desensitization is insensitive to agonist concentration and therefore requires other explanations. In our opinion, the acceleration of the $I_{\mathrm{Gly}}$ decay can be explained by the slow block of the open channel or/and the acceleration of the desensitization gate (Gielen et al., 2015). Other authors (Borovska et al., 2012; Vyklicky et al., 2016) described the acceleration of the decay of NMDA current under the influence of NS and explain this effect by slow NS diffusion to the site of action at the extracellular vestibule of the NMDAR. At present, we cannot give preference to any of these assumptions regarding the mechanisms for accelerating the desensitization of $I_{\mathrm{Gly}}$ under the influence of NS. This remains to be elucidated.

Interestingly, in the literature, we have not found any indications of the ability of NS to accelerate the desensitization of $I_{\mathrm{Gly}}$. The published studies of the action of steroids on $I_{\mathrm{Gly}}$ were performed on recombinant GlyRs expressed in frog oocytes (Maksay et al., 2001), a chicken spinal neuron culture (Wu et al., 1990), and a rat hippocampal and spinal neuron culture (Jiang et al., 2009). In all of the described models available in the literature, the authors describe a decrease in the $I_{\mathrm{Gly}}$ peak amplitude under the influence of NS. The reason for this contradiction may be due to the features of the methodological approach. We use short (600-1000 ms) co-application of glycine and NS, while other authors used 10-30 s pre-application of the NS followed by 10-15 s application of glycine along with the NS. It is possible that the prolonged exposure of NS to the nerve cell leads to a change in properties of the structures responsible for the desensitization of the GlyRs. However, this issue requires special research. The $\mathrm{IC}_{50}$ values for the effect of compounds 1-9 on the $\tau_{\text {des }}$ of $I_{\mathrm{Gly}}$ were in the range of $0.12-0.49 \mu \mathrm{M}$, and on the peak amplitude - in the range of 16-22 $\mu \mathrm{M}$. Our results are consistent with data from other authors who studied the effects of androsta(e)ne steroids with substitutions at C-17 on GlyRs. Maksay et al. (2001) showed that DHEA sulfate inhibits the recombinant GlyRs expressed in frog oocytes with an $\mathrm{IC}_{50}$ value of $2.5-6.3 \mu \mathrm{M}$.

As mentioned previously, GlyR-modulating compounds offer great potential for research on novel drug-like compounds. However, their parallel effect on $\mathrm{GABA}_{\mathrm{A}} \mathrm{R}$ might be a disadvantage from the pharmacological perspective. Therefore, the discovery of a selective steroidal modulator of GlyR is a challenging task that has not been, according to our knowledge, described previously in the literature. Here, we demonstrate that the addition of compounds $3,5,6$, and 9 at a concentration of 0.1-50 $\mu \mathrm{M}$ did not change either the peak amplitude or the rate of desensitization of $I_{\mathrm{GABA}}$ in isolated Purkinje cells. In contrast, compounds $\mathbf{1}, \mathbf{2}, \mathbf{4}, 7$, and 8 at $50 \mu \mathrm{M}$ concentration showed an inhibitory effect with a decrease in the peak amplitude of the current by $14-25 \%(P<0.01$ or $P<0.05)$ and the acceleration of its desensitization by $23-45 \%(P<0.01)$. We conclude that compounds $\mathbf{3}, \mathbf{5}, \mathbf{6}$, and $\mathbf{9}$ are selective modulators of $I_{\mathrm{Gly}}$. Their structures, however, do bear similar structural features to those that were able to affect $I_{\mathrm{GABA}}$. Therefore, establishing a pharmacophore from these results would be highly speculative. The data from the literature clearly indicate that a combination of C-3 and C-5 stereochemistry or the presence of double bond (4-ene/5-ene) of a steroid skeleton direct the effect on GlyRs and $\mathrm{GABA}_{\mathrm{A}}$ Rs activity (Park-Chung et al., 1999; Maksay et al., 2001; Fodor et al., 2006). Unfortunately, a simple additive approach cannot define pharmacophore for the desired combination of activity on one or both receptors. It is important to highlight that saturated $5 \alpha-\mathrm{H}$ and unsaturated (4-ene/5-ene) steroidal skeletons possess a planar shape of the molecule, while the $5 \beta-\mathrm{H}$ skeleton is a "bent" structure. The global shape of the molecule is then significantly affected by the stereochemistry of the C-3 substituent. Note, that the 
$3 \alpha$-hydroxy group of the planar $5 \alpha-\mathrm{H}$ skeleton is axial, whereas the $3 \alpha$-hydroxy group of the bent $5 \beta-\mathrm{H}$ skeleton is equatorial. Next, in case the substituent at C-3 is a carbonyl group, its location is in between axial and equatorial configuration. Finally, the nature of the modulatory effect seems to be defined by the substituent at position C-17. Taken together with the previously mentioned facts, we believe that we cannot define a pharmacophore for NS that would afford its modulatory action. Rather, a delicate balance of structural features at positions $\mathrm{C}$ 3, C-5, and C-17 could manage this extremely challenging task. The results of our unique study confirm this hypothesis. Our discovery of steroidal selective modulators of $I_{\mathrm{Gly}}$ provides a great potential for further structure-activity relationship studies affording novel compounds. Moreover, such research could lead to the identification of structural requirements of giving active compounds.

\section{DATA AVAILABILITY STATEMENT}

All datasets generated for this study are included in the article/supplementary material.

\section{REFERENCES}

Aroeira, R. I., Ribeiro, J. A., Sebastião, A. M., and Valente, C. A. (2011). Age-related changes of glycine receptor at the rat hippocampus: from the embryo to the adult. J. Neurochem. 118, 339-353. doi: 10.1111/j.1471-4159.2011.07197.x

Baulieu, E. E. (1998). Neurosteroids: a novel function of the brain. Psychoneuroendocrinology 23, 963-987. doi: 10.1016/s0306-4530(98)00071-7

Belelli, D., and Lambert, J. J. (2005). Neurosteroids: endogenous regulators of the GABA(A) receptor. Nat. Rev. Neurosci. 6, 565-575. doi: 10.1038/nrn1703

Borovska, J., Vyklicky, V., Stastna, E., Kapras, V., Slavikova, B., Horak, M., et al. (2012). Access of inhibitory neurosteroids to the NMDA receptor. Br. J. Pharmacol. 166, 1069-1083. doi: 10.1111/j.1476-5381.2011.01816.x

Bukanova, J. V., Solntseva, E. I., Kolbaev, S. N., and Kudova, E. (2018). Modulation of GABA and glycine receptors in rat pyramidal hippocampal neurons by $3 \alpha 5 \beta$-pregnanolone derivates. Neurochem. Int. 118, 145-151. doi: 10.1016/j. neuint.2018.06.002

Burnell, E. S., Irwin, M., Fang, G., Sapkota, K., Jane, D. E., and Monaghan, D. T. (2019). Positive and negative allosteric modulators of N-methyl-D-aspartate (n.d.) receptors: structure-activity relationships and mechanisms of action. J. Med. Chem. 62, 3-23. doi: 10.1021/acs.jmedchem.7b01640

Chen, Z. W., Bracamontes, J. R., Budelier, M. M., Germann, A. L., Shin, D. J., Kathiresan, K., et al. (2019). Multiple functional neurosteroid binding sites on GABAA receptors. PLoS Biol. 17:e3000157. doi: 10.1371/journal.pbio.300 0157

Do Rego, J. L., Seong, J. Y., Burel, D., Leprince, J., Luu-The, V., Tsutsui, K., et al. (2009). Neurosteroid biosynthesis: enzymatic pathways and neuroendocrine regulation by neurotransmitters and neuropeptides. Front. Neuroendocrinol. 30:259-301. doi: 10.1016/j.yfrne.2009.05.006

Dougherty, J. D., Maloney, S. E., Wozniak, D. F., Rieger, M. A., Sonnenblick, L., Coppola, G., et al. (2013). The disruption of Celf6, a gene identified by translational profiling of serotonergic neurons, results in autism-related behaviors. J. Neurosci. 33, 2732-2753. doi: 10.1523/JNEUROSCI.4762-12.2013

Fodor, L., Boros, A., Dezso, P., and Maksay, G. (2006). Expression of heteromeric glycine receptor-channels in rat spinal cultures and inhibition by neuroactive steroids. Neurochem. Int. 49, 577-583. doi: 10.1016/j.neuint.2006. 04.013

Ganser, L. R., and Dallman, J. E. (2009). Glycinergic synapse development, plasticity, and homeostasis in zebrafish. Front. Mol. Neurosci. 2:30. doi: 10.3389/ neuro.02.030.2009

\section{ETHICS STATEMENT}

The study was approved by the Ethics Committee of the Scientific Center of Neurology, Protocol No. 2-5/19 of 02.20.19.

\section{AUTHOR CONTRIBUTIONS}

JB conducted experiments to study the effects of neurosteroids on GABA- and glycine-activated current in rat neurons. ES wrote a physiological part of the manuscript. EK prepared compounds 6-9 as described in Materials and Methods section and wrote a chemical part of the manuscript.

\section{FUNDING}

This work was supported by Technology Agency of the Czech Republic: Czech National Centres of Competence, project "PerMed" Personalized Medicine - Diagnostics and Therapy TN01000013, and ERDF/ESF Project "PharmaBrain," Grant CZ.02.1.01/0.0/0.0/16_025/0007444 and by Academy of Sciences of the Czech Republic (AS CR) - grant RVO 61388963.

Gibbs, T. T., Russek, S. J., and Farb, D. H. (2006). Sulfated steroids as endogenous neuromodulators. Pharmacol. Biochem. Behav. 84, 555-567. doi: 10.1016/j.pbb. 2006.07.031

Gielen, M., Thomas, P., and Smart, T. G. (2015). The desensitization gate of inhibitory Cys-loop receptors. Nat. Commun. 6:6829. doi: 10.1038/ ncomms7829

Jiang, P., Kong, Y., Zhang, X. B., Wang, W., Liu, C. F., and Xu, T. L. (2009). Glycine receptor in rat hippocampal and spinal cord neurons as a molecular target for rapid actions of 17-beta-estradiol. Mol. Pain 5:2. doi: 10.1186/1744-8069-5-2

Jiang, P., Yang, C. X., Wang, Y. T., and Xu, T. L. (2006). Mechanisms of modulation of pregnanolone on glycinergic response in cultured spinal dorsal horn neurons of rat. Neuroscience 141, 2041-2050. doi: 10.1016/j.neuroscience.2006.05.009

Katona, B. W., Krishnan, K., Cai, Z. Y., Manion, B. D., Benz, A., Taylor, A., et al. (2008). Neurosteroid analogues. 12. Potent enhancement of GABA-mediated chloride currents at GABAA receptors by ent-androgens. Eur. J. Med. Chem. 43, 107-113. doi: 10.1016/j.ejmech.2007.02.017

Keck, T., and White, J. A. (2009). Glycinergic inhibition in the hippocampus. Rev. Neurosci. 20, 13-22. doi: 10.1515/revneuro.2009.20.1.13

Kelley, M. H., Ortiz, J., Shimizu, K., Grewal, H., Quillinan, N., and Herson, P. S. (2013). Alterations in Purkinje cell GABAA receptor pharmacology following oxygen and glucose deprivation and cerebral ischemia reveal novel contribution of $\beta 1$-subunit-containing receptors. Eur. J. Neurosci. 37, 555-563. doi: 10.1111/ ejn. 12064

King, S. R. (2013). Neurosteroids and the Nervous System. New York, NY: SpringerVerlag, 125. doi: 10.1007/978-1-4614-5559-2

Korinek, M., Kapras, V., Vyklicky, V., Adamusova, E., Borovska, J., Vales, K., et al. (2011). Neurosteroid modulation of N-methyl-D-aspartate receptors: molecular mechanism and behavioral effects. Steroids 76, 1409-1418. doi: 10. 1016/j.steroids.2011.09.002

Kung, A. Y., Rick, C., O'Shea, S., Harrison, N. L., and McGehee, D. S. (2001). Expression of glycine receptors in rat sensory neurons vs. HEK293 cells yields different functional properties. Neurosci. Lett. 309, 202-206. doi: 10.1016/ s0304-3940(01)02066-3

Laurie, D. J., Wisden, W., and Seeburg, P. H. (1992). The distribution of thirteen GABAA receptor subunit mRNAs in the rat brain. III. Embryonic and postnatal development. J. Neurosci. 12, 4151-4572.

Li, W., Jin, X., Covey, D. F., and Steinbach, J. H. (2007). Neuroactive steroids and human recombinant rhol GABAC receptors. J. Pharmacol. Exp. Ther. 323, 236-247. doi: 10.1124/jpet.107.127365 
Liu, X. K., Ye, B. J., Wu, Y., Nan, J. X., Lin, Z. H., and Piao, H. R. (2012). Synthesis and antitumor activity of dehydroepiandrosterone derivatives on Es-2, A549, and HepG2 cells in vitro. Chem. Biol. Drug Des. 79, 523-529. doi: 10.1111/j. 1747-0285.2011.01311.x

Lynch, J. W. (2004). Molecular structure and function of the glycine receptor chloride channel. Physiol. Rev. 84, 1051-1095. doi: 10.1152/physrev.00042.2003

Lynch, J. W. (2009). Native glycine receptor subtypes and their physiological roles. Neuropharmacology 56, 303-309. doi: 10.1016/j.neuropharm.2008.07.034

Lynch, J. W., Zhang, Y., Talwar, S., and Estrada-Mondragon, A. (2017). Glycine receptor drug discovery. Adv. Pharmacol. 79, 225-253. doi: 10.1016/bs.apha. 2017.01.003

Majewska, M. D., Mienville, J. M., and Vicini, S. (1988). Neurosteroid pregnenolone sulfate antagonizes electrophysiological responses to GABA in neurons. Neurosci. Lett. 90, 279-284. doi: 10.1016/0304-3940(88)90202-9

Maksay, G., Laube, B., and Betz, H. (2001). Subunit-specific modulation of glycine receptors by neurosteroids. Neuropharmacology 41, 369-376. doi: 10.1016/ s0028-3908(01)00071-5

Möhler, H. (2006). GABAA receptors in central nervous system disease: anxiety, epilepsy, and insomnia. J. Recept. Signal Transduct. Res. 26, 731-740. doi: 10. 1080/10799890600920035

Park-Chung, M., Malayev, A., Purdy, R. H., Gibbs, T. T., and Farb, D. H. (1999). Sulfated and unsulfated steroids modulate $\gamma$-aminobutyric acidA receptor function through distinct sites. Brain Res. 830, 72-87. doi: 10.1016/s00068993(99)01381-5

Pirker, S., Schwarzer, C., Wieselthaler, A., Sieghart, W., and Sperk, G. (2000). GABAA receptors: immunocytochemical distribution of 13 subunits in the adult rat brain. Neuroscience 101, 815-850. doi: 10.1016/s0306-4522(00) 00442-5

Rebas, E., Radzik, T., Boczek, T., and Zylinska, L. (2017). Calcium-engaged mechanisms of nongenomic action of neurosteroids. Curr. Neuropharmacol. 15, 1174-1191. doi: 10.2174/1570159X15666170329091935

Seljeset, S., Laverty, D., and Smart, T. G. (2015). Inhibitory neurosteroids and the GABAA receptor. Adv. Pharmacol. 72, 165-187. doi: 10.1016/bs.apha.2014. 10.006

Sieghart, W., and Savić, M. M. (2018). International union of basic and clinical pharmacology. CVI: GABAA receptor subtype- and function-selective ligands: key issues in translation to humans. Pharmacol. Rev. 70, 836-878. doi: 10.1124/ pr.117.014449

Tanabe, M., Nitta, A., and Ono, H. (2010). Neuroprotection via strychninesensitive glycine receptors during post-ischemic recovery of excitatory synaptic transmission in the hippocampus. J. Pharmacol. Sci. 113, 378-386. doi: 10.1254/ jphs.10150fp

Tapia, J. C., Cárdenas, A. M., Nualart, F., Mentis, G. Z., Navarrete, R., and Aguayo, L. G. (2000). Neurite outgrowth in developing mouse spinal cord neurons is modulated by glycine receptors. Neuroreport 11, 3007-3010. doi: 10.1097/ 00001756-200009110-00036
Vorobjev, V. S. (1991). Vibrodissociation of sliced mammalian nervous tissue. J. Neurosci. Methods 38, 145-150. doi: 10.1016/0165-0270(91)90164-u

Vorobjev, V. S., Sharonova, I. N., and Haas, H. L. (1996). A simple perfusion system for patch-clamp studies. J. Neurosci. Methods 68, 303-307. doi: 10.1016/01650270(96)00097-0

Vyklicky, V., Smejkalova, T., Krausova, B., Balik, A., Korinek, M., Borovska, J., et al. (2016). Preferential inhibition of tonically over phasically activated NMDA receptors by pregnane derivatives. J. Neurosci. 36, 2161-2175. doi: 10.1523/ JNEUROSCI.3181-15.2016

Weir, C. J., Ling, A. T., Belelli, D., Wildsmith, J. A., Peters, J. A., and Lambert, J. J. (2004). The interaction of anaesthetic steroids with recombinant glycine and GABAA receptors. Br. J. Anaesth. 92, 704-711. doi: 10.1093/bja/aeh125

Wu, F. S., Chen, S. C., and Tsai, J. J. (1997). Competitive inhibition of the glycineinduced current by pregnenolone sulfate in cultured chick spinal cord neurons. Brain Res. 750, 318-320. doi: 10.1016/s0006-8993(97)00053-x

Wu, F. S., Gibbs, T. T., and Farb, D. H. (1990). Inverse modulation of gamma-aminobutyric acid- and glycine-induced currents by progesterone. Mol. Pharmacol. 37, 597-602.

$\mathrm{Xu}$, T. L., and Gong, N. (2010). Glycine and glycine receptor signaling in hippocampal neurons: diversity, function and regulation. Prog. Neurobiol. 91, 349-361. doi: 10.1016/j.pneurobio.2010.04.008

Yevenes, G. E., and Zeilhofer, H. U. (2011). Allosteric modulation of glycine receptors. Br. J. Pharmacol. 164, 224-236. doi: 10.1111/j.1476-5381.2011. 01471.x

Zhang, Y., Ho, T. N. T., Harvey, R. J., Lynch, J. W., and Keramidas, A. (2017). Structure-function analysis of the GlyR $\alpha 2$ subunit autism mutation p.R323L reveals a gain-of-function. Front. Mol. Neurosci. 10:158. doi: 10.3389/fnmol. 2017.00158

Ziegler, E., Bodusch, M., Song, Y., Jahn, K., Wolfes, H., Steinlechner, S., et al. (2009). Interaction of androsterone and progesterone with inhibitory ligand-gated ion channels: a patch clamp study. Naunyn Schmiedebergs Arch. Pharmacol. 380, 277-291. doi: 10.1007/s00210-009-0440-x

Zorumski, C. F., Paul, S. M., Izumi, Y., Covey, D. F., and Mennerick, S. (2013). Neurosteroids, stress and depression: potential therapeutic opportunities. Neurosci. Biobehav. Rev. 37, 109-122. doi: 10.1016/j.neubiorev.2012.10.005

Conflict of Interest: The authors declare that the research was conducted in the absence of any commercial or financial relationships that could be construed as a potential conflict of interest.

Copyright (c) 2020 Bukanova, Solntseva and Kudova. This is an open-access article distributed under the terms of the Creative Commons Attribution License (CC BY). The use, distribution or reproduction in other forums is permitted, provided the original author(s) and the copyright owner(s) are credited and that the original publication in this journal is cited, in accordance with accepted academic practice. No use, distribution or reproduction is permitted which does not comply with these terms. 